\title{
SECOND THOUGHTS ON HALOTHANE IN NEUROSURGERY
}

\author{
R. G. B. GாвERT, M.B., F.R.G.P.(C), F.F.A.R.C.S., \\ R. A. MIILAR, M.D., M.SC., F.F.A.R.C.S., and \\ G. F. BRINDLE, B.A., M.D., C.M., F.R.C.P. $(\mathrm{C})^{1}$
}

IT Is Now more than two years since the representatives of Canadian universities reported before the Society their initial studies with halothane, and in the interim the pharmacology and clinical use of halothane have been extensively investigated. Though the eardiovascular effects of halothane and of chloroform are strikingly similar, there is as yet no concrete evidence that halothane is a potential liver poison when administered with the aid of modern anaesthetic techniques (whose superiority to those available when chloroform was first employed is obvious). It can be assumed, therefore, that halothane merits a secure place in anaesthesia although it is open to question whether future progress in anaesthesia depends upon the use of the volatile anaesthetics.

We have found halothane to be a valuable agent in neurosurgical anaesthesia, and report here some general impressions derived from our experience with this agent.

\section{RADIOLOGICAL INVESTKGATIONS}

One indication for the use of halothane is the arteriogram or other procedure requiring light anaesthesia, where an explosive hazard exists.. Following intubation by the thiopental-relaxant technique, light anaesthesia with $0.5-1.0$ per cent halothanê in 50 per cent nitrous oxide-oxygen has replaced former methods involving the use of trichlorethylene with or without intermittent thiopental injections. In a series of 179 patients (ages 6-66 yeärs) anaesthetized in this way with halothane, systolic blood pressure levels below $90 \mathrm{~mm}$. $\mathrm{Hg}$ occurred at some time during the administration in 32 patients, an incidence of 18 per cent. This degree of hypotension may, therefore, be expected in one out of every five or six patients adequately anaesthetized with nitrous oxide-oxygen-halọthane fòr minor or superficial surgical procedures. In this series, blood pressure frequently returned to leyels above $90 \mathrm{~mm} . \mathrm{Hg}$, either spontaneously or by a reduction in the inspired halothane concentration, but vasopressor drugs, .usually methoxamine, were given in 13 of the 32 patients showing levels below $90 \mathrm{~mm}$. $\mathrm{Hg}$ : that is, falls in blood pressure during halothane administration were considered to require treatment in only 7 per cent of the patients in this series. The procedures have been otherwise uneventful, without troublesome cardiac arrhythmias or falls in blood pressure associated with dye injection.

\section{Surgeny of the Vertebral. Columin and Spinal Cord}

Halothane has played an important part in the major change in anaesthe technique which has resulted from the use of controlled respiration in neu ${ }^{1}$ Montreal Neurological Institute and McGill University, Montreal, P.Q. 
surgery in this unit. Thus, positive-negative phase mechanical ventilators have been used in conjunction with nitrous oxide-oxygen-halothane anaesthesia in more than 150 major neurosurgical procedures, most of which involved an extensive and sometimes prolonged removal of single or multiple lumbar intervertebral disc protrusions. In this field spinal anaesthesia was previously found to be especially successful in minimizing epidural venous bleeding, producing distinctly better operating conditions than general anaesthesia with spontaneous respiration. It is our opinion, however, that mechanical ventilators have revolutionized general anaesthetic techniques, giving results which equal or surpass conditions thought to be attainable only by spinal (or epidural) blockade.

Halothane may be safely employed with mechanical respirators provided that vapour concentration is controlled independently of tidal volume. We have con"tinued to employ the Marrett apparatus, with gas flows up to $10 \mathrm{~L}$. per minute and with the "trichlorethylene" bottle containing 2 oz. of halothane. The concentration of halothane feeding the respirator does not exceed 1.5 per cent, therefore, and below 1 per cent is usually sufficient. The Bennett "assister" has been the preferred type, used only as a controlled respiration unit, with pressures of about +15 and $-5 \mathrm{~cm} . \mathrm{H}_{2} \mathrm{O}$.

After intubation with the thiopental-relaxant technique (or under thiopental anaesthesia induced after transtracheal injection of 4 per cent Xylocaine), apnoea can frequently be maintained with nitrous oxide-oxygen halothane alone. More usually, injections of tubarine maintain relaxation, and we have not found the combination of tubarine and halothane to present any special problem; although a variable, usually small, fall in systolic pressure occurs within a few $\mathrm{m}^{\text {inutes }}$ of injecting tubarine (not only during halothane anlesthesia), in our experience an adequate pressure level is re-established after a few minutes without the need for vasopressors.

With this technique, excellent conditions are obtained for the surgery of the spinal canal. Venous drainage of the epidural veins appears excellent, the spinal dura visibly expanding and collapsing during the positive and negative respirator phases. It is our view that when optimal ventilation is achieved by means of positive-negative pressure ventilation, management of the circulation is simplified. By judicial increases in halothane concentration, controlled degrees of arterial hypotension can provide a dry surgical field. It should be emphasized that - patients with spinal fractures are highly sensitive to the hypotensive action of halothane, and accurate blood pressure measurement is essential for the safe management of such patients, who behave similarly during either spontaneous or controlled respiration.

\section{Intracranial Procedures}

For many years, and in spite of theoretical objections, nitrous oxide-oxygenether has been the mainstay in the anaesthetic mạnagement of all varieties of neurosurgical procedures in this unit. Halothane is now a valuable adjunct, and under certain circumstances has replaced ether, allowing a more rapid recovery from prolonged neurosurgical procedures. Unfortunately, the use of halothane is restricted by surgical infiltration of the operation site with local analgesic solution 
containing adrenalin, which introduces an unpredictable hazard, necessitating the temporary use of other agents (thiopental, Demerol, or ether) for periods of at least ten minutes before and 30 minutes after injection of analgesic solution.

The reduction in haemorrhage obtained by the use of positive-negative pressure ventilation is less obvious in intracranial surgery than in spinal procedures. Clearly, when intracranial tension is increased by: a space-occupying lesion, mechanical ventilators will be relatively ineffective in promoting a fall in cerebrospinal fluid and intracranial venous pressures. On the other hand, sudden increases' in intracranial tension, secondary to coughing or straining, are absent, so that the use of the respirator technique when properly managed is a valuable preventive measure against the poor operating conditions sometimes seen during general anaesthesia with spontaneous respiration.

As an aid in the intracranial exposure of vascular aneurysms, pituitary tumours, and acoustic nerve tumours, the halothane/respirator technique is excellent; in combination with lumbar drainage, or with intravenous injection of urea solutions, maximum brain shrinkage is obtainable. Here, also, the hypoteasivo properties. of halothane are advantageous. When hypertension accompanies brain swelling, secondary to haemorrhage near the brain stem, halothane has been given in stronger concentrations to reduce blood pressure and minimize further brain swelling.

\section{RÉSUMÉ}

En anesthésie neurochirürgicạle, nous avons trouvé que l'halothane est un agent de valeur. L'emploi de thalothane trouve une indication dans les cas d'artériogrammes et dans d'autres circonstances où une anesthésie légère est requise et où il existe un risque d'explosion. On peut s'attendre à une hypotension systolique au-dèssous de $90 \mathrm{~mm}$. Hg chez un sur cinq ou six malades adéquatement anesthésiés avec protoxide d'azote-oxygène-halothane pour des interventions chirurgicales mineures ou superficielles.

Nous avons employé des ventilateurs à phase positive-négative au cours dẹ l'anesthésie avec protoxide d'azote-oxygène-halothane pour au-delà de 150 opérations majeures neurochirurgicales dont la plupart consistaient en l'ablation extensive et quelquefois prolongée de disques intervertébraux lombaires herniés. Nous sommes d'avis que, dans ce domaine, les. ventilateurs , mécaniques ont révolutionné les techniques d'anesthésie générale en permettant d'obtenir des résultats égaux et même surpassant ce que nous croyions pouvoir obtenir seulemènt avec la rachianesthésie ou le blocage épidural:

Avec les respirateurs mécaniques, il est possible d'employer l'halothane pourvu que, en dehors de l'air courant, la concentration des vapeurs soit contrôlée.

Pour l'anesthésie au cours des opérations intracrâniennes, l'halothane est une précieuse acquisition qui, en certaines circonstances, a remplacé l'éther en permettant un réveil plus précoce à la suite d'opérations neurochirurgicales prolongées. Mentionnons', toutefois, que l'emploi de l'halothane n'est pas compatible avec l'infiltration dans le site opératoire d'un anesthésique local contenant de l'adrénaline, ce qui pourrait apporter un risque imprévisible. La diminution de l'hémorragie obtenue par l'usage de la ventilation à pression positive et négativè 
est moins évidente au cours de la chirurgie intracrânienne qu'au cours des opérations sur la colonne vertébrale.

Les vertus hypotensive de l'halothane présentent un avantage en aidant d visualiser dans le crâne les anévrysmes vasculaires, les tumeurs de la pituitaire et les tumeurs du nerf acoustique. Quand l'hypertension s'accompagne d'un gonflement du cerveau, nous avons donné des concentrations plus élevées d'halothane dans le but de réduire la tension sanguine et de diminuer le gonflement cérébral.

\section{REFERENCE}

Brindle, G. F., Gilbert, R. G. B., \& Millar, R. A. The Use of Fluothane in Anaesthesia for Neurosurgery: A Preliminary Report. Canad. Anaesth. Soc. J. 4: 265 (July 1957). 